\title{
Assessment of the Potential of Sugarcane Bagasse to Mitigate Clayey Soil Cracks Using Image Processing Technique: Laboratory Experiment
}

\author{
A.A. Abd El-Halim \\ Department of Soil and Water, Faculty of Agriculture, \\ University of Tanta, 31527 Tanta, Egypt
}

\begin{abstract}
T $\mathrm{N}$ THE AGRICULTURAL soils, desiccation cracks control the rate and velocity at which water, solutes, and micro-organisms are transported in the soil profile, and thus significantly affect the growth and yield of crops. Therefore, the effect of bagasse added to clay soil on suppressing desiccation cracks and the influencing factors behind the cracking behavior i.e., volumetric shrinkage and water retention property of clay soil were investigated experimentally under proper laboratory environment. To fulfill this objective, clay soils were amended using bagasse at a rate of $0,1,2,3,4$ and $5 \%$ on the dry weight basis. Various experimental methods were used to determine the variations in volumetric shrinkage and water holding capacity, while crack intensity factor and cracking width were determined using the image processing technique by ImageJ ver. 1.47 software for different bagasse-amended soils. Results showed that fine bagasse had the potential to improve water holding capacity and reduce volumetric shrinkage strain and thus reduce the cracks development at desiccation of the clay soil. Also, results suggested that addition of bagasse to clay soil was an available and simple method to mitigate desiccation cracks, especially when mixed with soil in rates between 1 and $2 \%$ on the dry weight basis. Above this percentage reducing the development of desiccation cracks was not significant.
\end{abstract}

Key words: Volumetric shrinkage; Water holding capacity; Soil cracking behavior; Bagasse

Clayey soils contain silicate clay minerals that have the potential for swelling and shrinkage under changing moisture contents. Shrinkage and swelling cause the formation of field feature, namely, cracks.

In the agricultural soil, desiccation cracks significantly affect the rate and velocity of water and solutes which are transported into the soil, and consequently the growth and yield of crops. Therefore, desiccation cracking has attracted much attention of researchers (e.g., Kishné et al., 2010; Li \& Zhang, 2011; Nahlawi \& Kodikara, 2006; Tang et al., 2008 and Tang et al., 2011).

Bagasse, the residue after pressing sugarcane stalks to extract the juice in sugar factories, normally deposited as waste, and often, being burnt under boilers

E-mail: halim.ismail@agr.tanta.edu.eg 
for heating the juice. These wastes need better utilization instead of burning. One of the promising approaches to utilize bagasse is the use as a low-cost soil amendment.

As reported in previous literature, in order to mitigate desiccation cracks of clay soils, various stabilization agents have been used. These agents include lime, fly ash, bagasse ash, silica fume, fiber, bentonite and sand (e.g., Harianto et al., 2008 and Osinubi \& Eberemu, 2008; Kalkan, 2009). A limited research has been done to quantify the beneficial effect of applying the fine bagasse to mitigate desiccation cracks of clayey soils.

An attempt is therefore made, herein, to mitigate desiccation cracks of clay soil using different percentages of fine bagasse additive, and investigate the influencing factors behind cracking behavior of soil such as volumetric shrinkage, clay content and water holding capacity experimentally under proper laboratory environment.

\section{Materials and Methods}

\section{Soil samples}

Clay soil samples were collected from the top soil layer $(20 \mathrm{~cm})$ on January 2015 from Desouk city, that belongs to Kafr el-Sheikh Governorate, Egypt, (latitude $31^{\circ} 8^{\prime} 32^{\prime \prime} \mathrm{N}$, longitude $30^{\circ} 38^{\prime} 42^{\prime \prime} \mathrm{E}$, and its altitude is nine meters above sea level). The soil samples were collected, air-dried, crushed, and sieved through a $2 \mathrm{~mm}$ sieve (ASTM No. 10) and then the primary physical properties (Table 1) were determined as described by Haluschak (2006).

TABLE 1. Physical properties of the study soil

\begin{tabular}{lc}
\hline \multicolumn{1}{c}{ Properties } & Values \\
\hline Specific gravity & 2.78 \\
Consistency limit & \\
Liquid limit, $w_{\mathrm{L}}(\%)$ & 68.57 \\
Plastic limit, $w_{\mathrm{P}}(\%)$ & 34.63 \\
Shrinkage limit, $w_{\mathrm{S}}(\%)$ & 20.37 \\
Plasticity index, PI $(\%)$ & 33.94 \\
Grain size analysis & \\
Sand $(\%)$ & 18.66 \\
Silt $(\%)$ & 34.23 \\
Clay $(\%)$ & 47.11 \\
\hline
\end{tabular}

\section{Bagasse}

The bagasse residue was used as an additive in the experimental procedure; it was obtained locally from sugarcane juice shops, air drying gently crushed, passed through a 1-mm sieve (ASTM No. 18), and stored in airtight containers to avoid pre-hydration until usage.

Egypt. J. Soil. Sci. 56, No. 4 (2016) 


\section{Preparation of soil/bagasse mixture treatments}

The soil and bagasse were blended to prepare soil/bagasse mixtures (Bagasseamended soil treatments) under the dry condition. The amounts of bagasse were selected to be $1,2,3,4$, and $5 \%$, in addition, $0 \%$ (non-amended soil, the control treatment), on the soil dry weight basis. All mixtures were done manually and proper care was taken to prepare homogeneous mixtures at each stage.

\section{Laboratory analyses}

Water-holding capacity (WHC) was determined at $-0.033 \mathrm{MPa}$ pressure using the pressure plate apparatus (Soil Moisture Equipment Corp., Santa Barbara, CA, USA) (Estefan et al., 2013).

Volumetric shrinkage strain $\left(\mathrm{V}_{\mathrm{s}}\right)$ tests were conducted using approximately 150 grams of the natural soil sample or bagasse-amended soil samples. The natural soil sample or bagasse-amended soil samples were transferred to glass plate and then water added and mixed thoroughly with palette knives until the mass became a smooth thick homogenous paste. The homogenous paste was placed in an airtight container and left for $24 \mathrm{hr}$ to enable the water to penetrate through the sample. The prepared sample was placed in a greased cylindrical aluminium can, its volume is $50 \mathrm{~cm}^{3}$, in three layers and tapped against a flat surface in between the layering to remove air bubbles from the sample, then allowed to dry in the air for four hours and placed in an oven at $105^{\circ} \mathrm{C}$ for $18 \mathrm{hr}$. After drying process, samples were allowed to cool. The process was replicated five times and the volume change of the sample from wet to oven dry was measured with sand method (Tariful et al., 1999) as follows: bulk samples of sand were dried, cleaned, and then sieved through a $212 \mu \mathrm{m}$ sieve (ASTM-E11 No. 70). Then the fine sand $\leq 212 \mu \mathrm{m}$ was slowly poured into the can that contains the dry soil sample until the can was completely filled up. During this process the can was knocked gently several times to ensure proper filling of the sand. Then, the top of cans was carefully leveled to remove excess sand using a sharp and thin knife. The sample and sand were then separated from the can and the sand was poured into a $50-\mathrm{ml}( \pm 0.5-\mathrm{mL})$ graduated measuring cylinder. This volume of sand so measured is equal to the volume change of the sample from wet to oven dry. The volume change of the five replicates was used to determine the volumetric shrinkage strains of the soil specimens. The volumetric shrinkage strain $\left(\mathrm{V}_{\mathrm{s}}\right)$ is defined as the change in volume $(\Delta \mathrm{V})$ to the total volume of the soil specimen $(\mathrm{V})(\%)$, expressed by:

$$
\mathrm{V}_{\mathrm{s}}(\%)=(\Delta \mathrm{V} / \mathrm{V}) \times 100
$$

Desiccation Cracking tests were conducted by mixing the natural soil or bagasseamended soils with distilled water at the gravimetric water content of about $90 \%$ $\left(\mathrm{g}, \mathrm{g}^{-1}\right)$ to obtain saturated specimens. The obtained saturated specimens were energetically mixed by hand, and then a desired quantity was poured into a plastic square tray $(100 \times 100 \mathrm{~mm}) 20 \mathrm{~mm}$ high side. To remove entrapped air bubbles in saturated specimens, these plates were placed on a vibrated device for $5 \mathrm{~min}$. Finally, the trays containing prepared saturated specimens were covered 
for at least $24 \mathrm{hr}$ for sedimentation. Prior to the test, the supernatant water above saturated specimen's surface was allowed to evaporate. The corresponding layer thickness was controlled to be $15 \mathrm{~mm}$. Three identical specimens from each treatment were prepared for desiccation test and then air dried on a laboratory table at a uniform temperature of $28 \pm 2{ }^{\circ} \mathrm{C}$ for a period of 25 days, until, the dehydration process was complete. After drying, the specimens were photographed to obtain crack pattern. The image acquisition was done by using a digital camera SONY DSC-T77 MKM, 10.1 mega pixels (Fig.1).

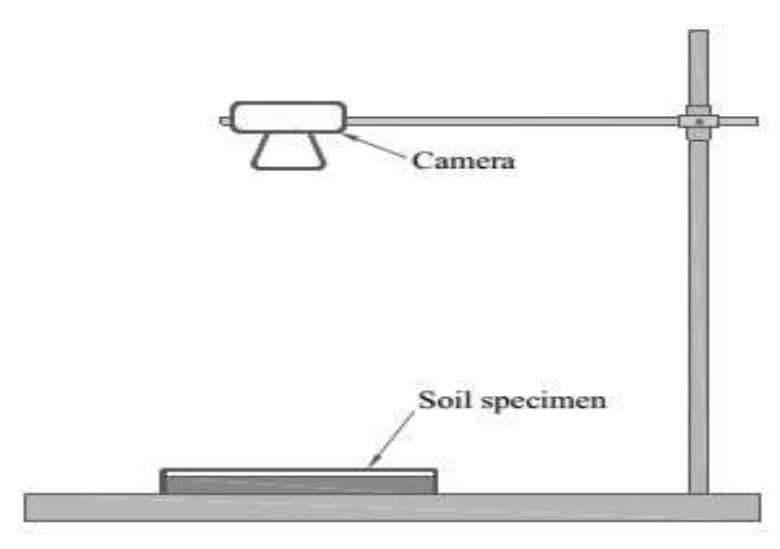

Fig. 1. Schematic drawing of set-up used in the desiccation test

Colour image of the desiccated sample $\left(100 \mathrm{~cm}^{2}\right)$ was taken. An ImageJ ver. 1.47 program was used to analyze the digital photographs of desiccating specimens. The primary image processing technique used in the research work was "thresholding". The purpose of "thresholding" is to select the pixel intensity value, which separates the objects from a general background. Ideally, after "thresholding", all cracked portions would be depicted as black pixels and soil as white pixels, and finally the crack intensity factor and crack width was calculated. The following step-by-step procedure of image processing which was used to measure the crack intensity factor (CIF) of the control and amended soils: 1. The digital photograph taken on the shrunk sample is downloaded into the computer.

2. The digital image of the picture taken is converted into a gray scale image.

3. A threshold value is then selected so that all the cracked area becomes black, and the remnant background becomes white. In briefly, the image is converted into a binary image.

4. The area $\left(\mathrm{A}_{\mathrm{c}}\right)$ of the threshold image in pixels is calculated using the "measure" function of the ImageJ software.

5. The area $\left(\mathrm{A}_{t}\right)$ of the total picture in pixels is also measured using the same "measure" function of the ImageJ software.

Egypt. J. Soil. Sci. 56, No. 4 (2016) 
The crack intensity factor (CIF) is then calculated by taking the ratio or percentage of the threshold image in pixels to the total area of the image in pixels. This equation presented in the following:

$$
\operatorname{CIF}(\%)=\left(\mathrm{A}_{\mathrm{c}} / \mathrm{A}_{\mathrm{t}}\right) \times 100
$$

where, $A_{c}$ is the desiccation cracks area, and $A_{t}$ is the total surface area of the specimen.

The crack width was measured at 15 points and the average of them was used $\left(\mathrm{W}_{\mathrm{av}}\right)$.

Statistical analysis

The data were analyzed statistically using MSTATC ${ }^{\mathrm{TM}}$ version 2.0. One-way ANOVA was used to determine statistically significant difference in all parameters among the tested samples. The significant differences between means were tested using Tukey's Honestly Significant Difference Test at the $5 \%$ level.

\section{Results and Discussion}

Effects of bagasse on water holding capacity (WHC)

The effect of bagasse on water holding capacity (WHC) is shown in Fig. 2. The 5, 4, and 3\% bagasse-amended soil treatments gave the highest values reached 41.64, 41.62 and $41.58 \%$, respectively. While the non-amended soil and both of $1 \%$ and $2 \%$ bagasse-amended soil treatments gave the lowest values being $37.57,38.72$ and $39.38 \%$, respectively. Water holding capacity (WHC) is highly correlated with bagasse content $\left(\mathrm{R}^{2}=0.94\right.$, Fig. 2). Moreover, the statistical analysis showed no significant differences between the 5, 4, and 3\% bagasse-amended soil treatments. However, the WHC increased with the 3, 4 and $5 \%$ bagasse-amended soil treatments by about $4 \%$ in comparison to nonamended soil treatment. The increase of WHC could be attributed to the nature of bagasse as organic matter helped to change the soil matrix (i.e., facilitated the coherent interaction of soil/bagasse or bagasse/bagasse particles), which resulted in increasing the soil aggregation, and thus increased the angular pores, which are responsible for holding more water by adhesive and cohesive forces. A number of authors have reported that the potential of agricultural and agroindustrial waste materials to facilitate cohesive interaction of soil/amendment particles (e.g., Rajor et al., 1996; Rawls et al., 2003; Ciroma et al., 2006; Eusufzai \& Fujii, 2012 and Hugar \& Soraganvi, 2014).

Effects of bagasse on the volumetric shrinkage strain $\left(V_{s}\right)$

The variances in the volumetric shrinkage strain $\left(\mathrm{V}_{\mathrm{s}}\right)$ based on the percentage of bagasse are illustrated in Fig. 3. The results showed that there were a highly correlation between bagasse content and the volumetric shrinkage strain $\left(\mathrm{R}^{2}=\right.$ $0.98)$. In addition, there were marked differences $(P \leq 0.001)$ in the volumetric shrinkage strain between the natural soil and other bagasse-amended soil treatments. The $\mathrm{V}_{\mathrm{s}}$ decreased from $41.36 \%$ with the non-amended soil treatment to $36.36 \%$ with the $5 \%$ bagasse-amended soil treatment. However, there were no significant differences between the 3, 4 and $5 \%$ bagasse-amended soil treatments. The $\mathrm{V}_{\mathrm{s}}$ strains observed with the non-amended soil were higher than that observed with the 1,2,3,4 and 5\% bagasse-amended soil treatments by 1.32 , $3.30,4.96,4.98$ and $5 \%$, respectively. 


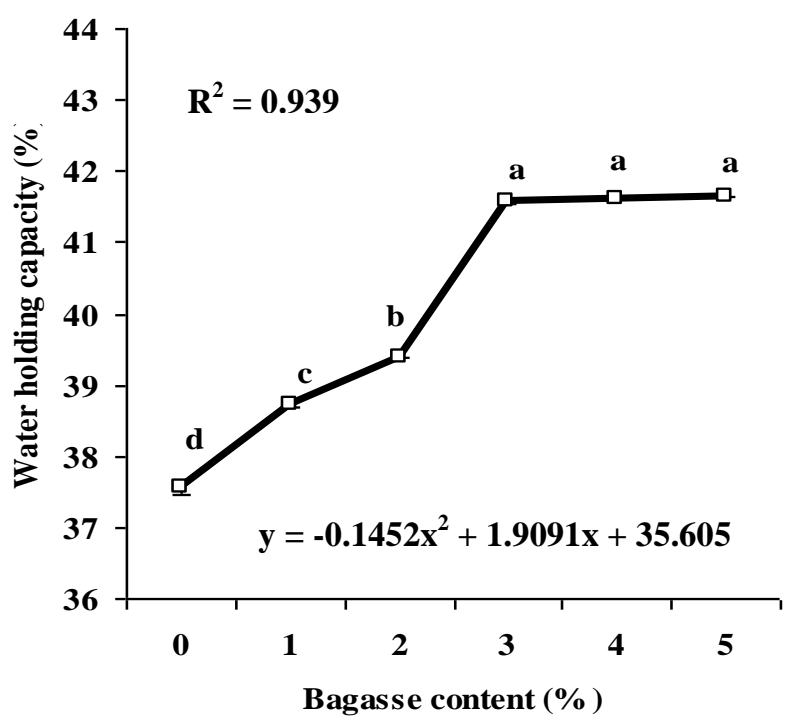

Fig. 2. The relationship between water holding capacity and bagasse content; error bar denotes the standard deviation; the small different letters (a, b, c and d) are denoting a significant difference between mean values (Tukey's test, $P \leq 0.001$ )

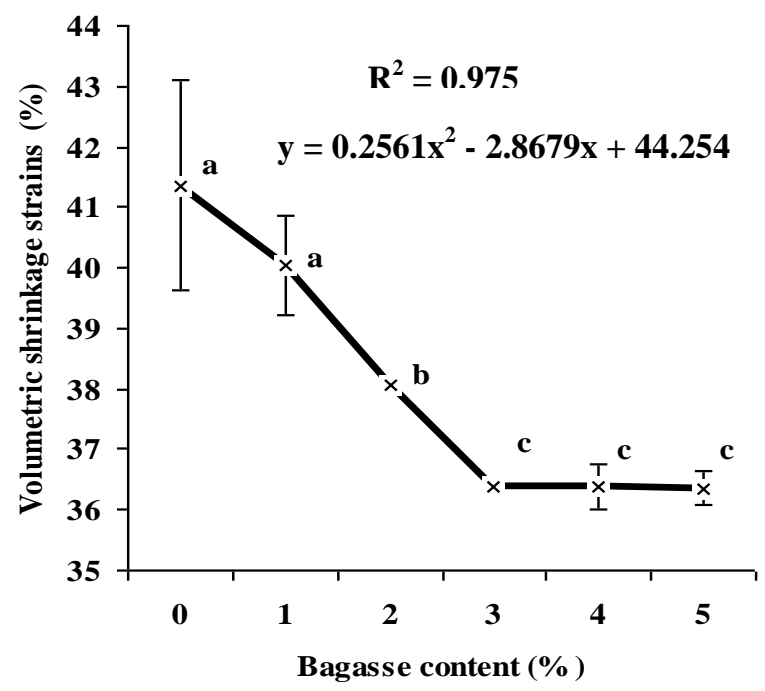

Fig. 3. The relationship between volumetric shrinkage strains and bagasse content; error bar is denotes the standard deviation; the small different letters $(a, b$ and c) are denoting a significant difference between mean values (Tukey's test, $\mathbf{P} \leq \mathbf{0 . 0 0 1}$ ) 
The results proved that increasing the bagasse content, volumetric shrinkage strain was reduced. This could be attributed to the decrease of the plasticity of bagasse-amended soil in comparison with non-amended soil. The decrease of shrinkage strains due to the decrease of the plasticity index has been indicated by many researchers (e.g., Hugar \& Soraganvi, 2014; Inci, 2008; Tang et al., 2008 and Tang et al., 2011). The bagasse is considered a non-plastic material, which led to decrease the plasticity index when blended with the soil. Thus, reduced the number of bonds between the clay particles with the increased bagasse/clay particle bonds or bagasse/bagasse particle bonds resulted in changing the bagasse-amended soil from high plasticity clay group to low plasticity clay group. Indeed, the mixture that has greater bagasse content reduces amplitude and shrinking pressure, where much of it is absorbed by the voids between coarse-grained materials formed due to bagasse/clay particle bonds or bagasse/bagasse particle bonds. A number of authors have referred to the capability of non-plastic agricultural and agro-industrial waste materials to reduce shrinkage strains of clayey soils (e.g., Bose, 2012; Prasad \& Sharma, 2014; Sabat \& Bose, 2013; Sharma \& Singh, 2013 and Singh et al., 2014).

Moreover, the increase of water holding capacity of the soil due to increase of bagasse percentage, as illustrated above, helped to hold more water, and thus, to shrink more upon drying.

Structure evolution and the geometric parameters of crack pattern after drying period

When studying clay cracking the quantitative analysis and the geometric parameters of the crack pattern are helpful in evaluating the hydro-mechanical properties of the clay-water system and providing a way to investigate the essential mechanisms of cracking. In addition, the geometric characteristics of the crack pattern reflect the material plasticity and mineral composition. Figure 4 (A, B and C) presents the typical black and white crack pattern after the drying period for the 0,1 and $2 \%$ bagasse-amended soil treatments, respectively, while Fig.4 (D, E and F) presents the typical crack pattern after the drying period for the 3,4 and $5 \%$ bagasse-amended soil treatments, respectively.

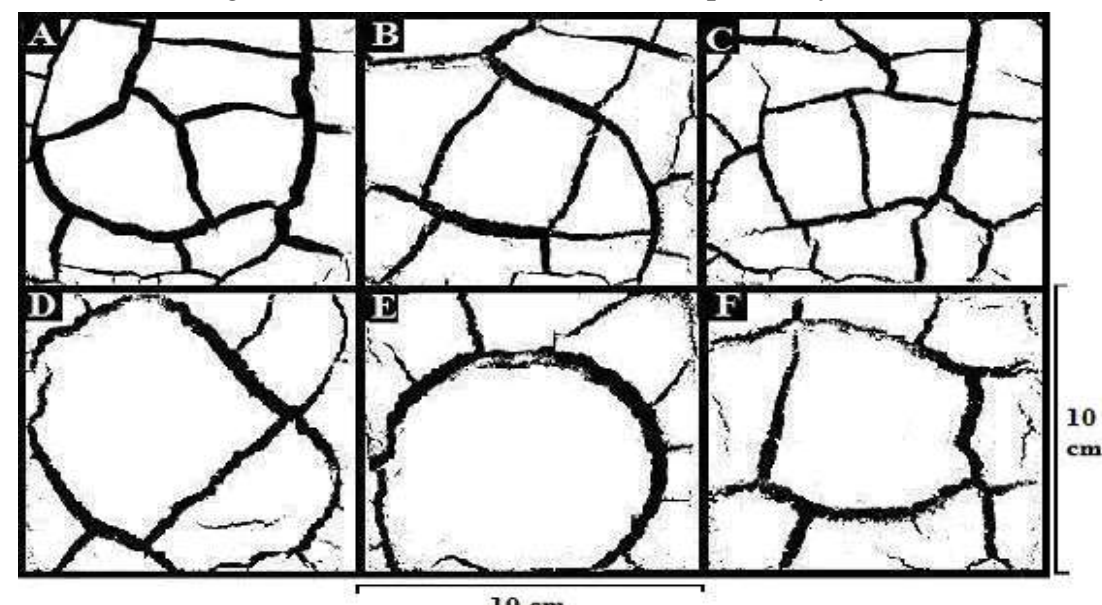

Fig. 4. The A, B, C, D, E, and F is the typical black and white desiccation crack patterns after drying period for the $0,1,2,3,4$, and $5 \%$ bagasse-amended soil treatments, respectively 
The shapes of the separated clods observed with Fig. 4 (D, E and F) were more irregular and the crack segments were more jagged than that observed in Fig. 4 (A, B and C). That means, the geometric and morphological characteristics of the crack patterns for the 0,1 and $2 \%$ bagasse-amended soil treatments are similar to each other after the drying period. Also, the geometric and morphological characteristics of the crack patterns for the 3, 4 and 5\% bagasseamended soil treatments are similar to each other after the drying period. This observation is consistent with the quantitative results of the geometric parameters of crack intensity factor (CIF) and average crack width $\left(\mathrm{W}_{\mathrm{av}}\right)$, which were determined from the final crack patterns after the drying period and summarized in Table 2.

TABLE 2. Mean values of crack quantitative parameters and the corresponding standard deviation (SD) after drying period for different bagasse content

\begin{tabular}{ccccc}
\hline Bagasse content $(\%)$ & CIF (\%) & SD of CIF & W $_{\text {av }}(\mathrm{mm})$ & SD of W \\
\hline 0 & $16.65^{\mathrm{a}}$ & 0.91 & $4.31^{\mathrm{cd}}$ & 0.98 \\
1 & $15.27^{\mathrm{a}}$ & 0.40 & $3.98^{\mathrm{cd}}$ & 0.82 \\
2 & $15.24^{\mathrm{a}}$ & 0.41 & $3.61^{\mathrm{d}}$ & 1.04 \\
3 & $13.75^{\mathrm{b}}$ & 0.69 & $4.76^{\mathrm{bc}}$ & 0.43 \\
4 & $13.27^{\mathrm{b}}$ & 0.24 & $5.71^{\mathrm{ab}}$ & 0.22 \\
5 & $13.18^{\mathrm{b}}$ & 0.16 & $5.76^{\mathrm{a}}$ & 0.71 \\
\hline
\end{tabular}

The CIF is the surface crack ratio and $\mathrm{W}_{\mathrm{av}}$ is the average crack width.

It was observed that there was a reduction in the development of desiccation crack with increasing bagasse content in between $1 \%$ and $5 \%$, where the crack intensity factor (CIF) decreased from $16.65 \%$ with the non-amended soil treatment to $13.18 \%$ with the $5 \%$ bagasse-amended soil treatment. The CIF with the 1 and $2 \%$ bagasse-amended soil treatments was reduced by about 1.38 and $1.41 \%$ and the $\mathrm{W}_{\mathrm{av}}$ by about 7.66 and $16.24 \%$, respectively, while with the 3,4 and $5 \%$ bagasse-amended soil treatments the CIF decreased by about 2.9, 3.38 and $3.47 \%$ and the $\mathrm{W}_{\mathrm{av}}$ increased by about $10.44,32.48$ and $33.64 \%$, respectively. In addition, the statistical analysis of the $\mathrm{R}_{\mathrm{sc}}$ indicated that there were differences $(\mathrm{P} \leq 0.001)$ between the non-amended soil treatment and the other bagasse-amended soil treatments. However, there were no significant differences between the non-amended soil and both of 1 and $2 \%$ bagasseamended soil treatments, and also between the 3,4 and 5\% bagasse-amended soil treatments. Based on the obtained values of CIF and $\mathrm{W}_{\mathrm{av}}$, it can be deduced that most of the formed cracks in the 1 and $2 \%$ bagasse-amended soil treatments are thin and threadlike, but with the 3,4 and 5\% bagasse-amended soil treatments are thick and wide in comparison to the natural soil. This may be due to the lower volumetric shrinkage strain of the 3, 4 and 5\% bagasse-amended soil treatment. In addition, higher amount of bagasse led to reduce the resistance (interfacial force, interlock force, and friction) between the soil and bagasse particles during the desiccation. This result supports the result of "in clay soils, higher CIF corresponds to higher soil shrinkage" (Tang, 2011); Also, supports

Egypt. J. Soil. Sci. 56, No. 4 (2016) 
the result of "the CIF was varied with the number of cracks per area, where the higher the number of cracks per area the higher was the CIF, but the opposite was found in the case of $\mathrm{W}_{\mathrm{av}}$ " (Atique and Sanchez, 2011).

\section{Conclusions}

In this study, the effect of bagasse added to clay soil on mitigating desiccation crack and the influencing factors behind the cracking behavior such as volumetric shrinkage and water retention property of clay soil; were investigated experimentally under proper laboratory environment. The results indicated that the improved soil-bagasse mixtures led to beneficial changes in the properties of clay soil (i.e. increased water holding capacity, reduced volumetric shrinkage strain, and reduced the crack intensity factor). The behavior of soil with bagasse additives in the desiccation crack test would be only due to the bagasse residues. This is mainly due to the interaction of soil particles and bagasse, which enhanced the resistance against crack. These results suggested that the addition of bagasse to clay soil is available method to mitigate desiccation crack, especially, when mixed with soil in rates between two to three percent on dry weight basis, and above this percentage the reduction development of desiccation crack was much less significant.

\section{References}

Atique, A. and Sanchez, M. (2011) Analysis of Cracking Behavior of Drying Soil [Internet]. $2^{\text {nd }}$ International Conference on Environmental Science and Technology IPCBEE, IACSIT Press, Singapore, 6, 66-70. [Cited 4 March 2015] Available from: http://www.ipcbee.com/vol6/no1/14-F00026.pdf

Boivin, P., Garnier, P. and Tessier D. (2004) Relationship between clay content, clay type, and shrinkage properties of soil samples. Soil Sci. Soc. Am. J. 68, 1145-1153.

Bose, B. (2012) Geo engineering properties of expansive soil stabilized with fly ash. Electron J. Geotech. Eng. 17 (Bund. I), 1339- 1353. [Cited 3 June 2014] Available from: http://www.ejge.com/2012/Ppr12.109alr.pdf

Chiroma, A.M., Folorunso, O.A. and Alhassan, A.B. (2006) The effects of land configuration and woodshavings mulch on the properties of a sandy loam soil in northeast Nigeria. 2. Changes in physical properties. Tropicultura. 24 (1), 33-38.

Estefan, G.; Sommer, R. and Ryan, J. (2013) Methods of soil, plant, and water analysis: A manual for the west, Asia and North Africa region. ICARDA, Beirut, Lebanon.

Eusufzai, M.K. and Fujii, K. (2012) Effect of Organic Matter Amendment on Hydraulic and Pore Characteristics of a Clay Loam Soil. Open J. Soil Sci. 2, 372-381.

Haluschak, P. (2006) Laboratory methods of soil analysis. Canada-Manitoba Soil Survey, p. 12-36. 
Harianto, T., Hayash, S., Du, Y.J. and Suetsugu, D. (2008) Effects of Fiber Additives on the Desiccation Crack Behavior of the Compacted Akaboku Soil as a Material for Landfill Cover Barrier. Water Air Soil Pollut, 194,141-149.

Hugar, G.M. and Soraganvi, V.S. (2014) Impact of Soil Organic carbon on Bulk Density and plasticity index of Arid Soils of Raichur, India. Int. Res. J. Env. Sci. 3 (2), 48-58.

Inci, G. (2008) Numerical Modeling of Desiccation Cracking in Compacted Soils. The $12^{\text {th }}$ International Conference of International Association for Computer Methods and Advances in Geomechanics (IACMAG), October 1-6, Goa, India, 1116-1125. [Cited 4 March 2015] Available from: http://citeseerx.ist.psu.edu/viewdoc/download?doi=10.1.1.384.3881andrep=rep1 andty pe $=$ pdf

Kalkan, E. (2009) Influence of silica fume on the desiccation cracks of compacted clayey soils. Appl. Clay Sci. 43, 296-302.

Kishné, A.S.Z., Morgan, C.L.S., Ge, Y. and Miller, W.L. (2010) Antecedent soil moisture affecting surface cracking of a Vertisol infield conditions. Geoderma. 157, 109-117.

Li, J.H. and Zhang, L.M. (2011) Study of desiccation crack initiation and development at ground surface. Eng. Geolog. 123, 347-358.

Nahlawi, H. and Kodikara, J.K. (2006) Laboratory experiments on desiccation cracking of thin soil layers. Geotech. Geol. Eng. 24, 1641-1664.

Osinubi, K.J. and Eberemu, A.O. (2008) Effect of Desiccation on Compacted Lateritic Soil Treated with Bagasse Ash. Materials Society of Nigeria (MSN) Zaria Chapter Book of Proceedings, $4^{\text {th }}$ edition.

Prasad, C.R.V. and Sharma, R.K. (2014) Influence of sand and fly ash on clayey soil stabilization. International Conference on Advances in Engineering and Technology (ICAET-2014), special issue. J. Mech. Civil. Eng. 4, 36-40.

Rajor, A., Sharma, R., Sood, V.K. and Ramamurthy, V. (1996) A sawdust-derived soil conditioner promotes plant growth and improves water-holding capacity of different types of soils. J. Ind. Microbiol. 16 (4), 237-240.

Rawls, W.J, Pachepsky, Y.A.; Ritchiea, J.C.; Sobeckic, T.M. and Bloodworth, H. (2003) Effect of soil organic carbon on soil water retention. Geoderma. 116 (1-2), 61-76.

Sabat, A.A. and Bose, B. (2013) Improvement in Geotechnical Properties of an Expansive Soil using Fly Ash-Quarry Dust Mixes. Electron J. Geotech. Eng. 18 (Bund. Q), 3487-3500.

Sharma, R.K. and Singh, B. (2013) Modification of clayey soil using fly ash. Int. J. Res. Eng. Tech. 2 (10), 356-361.

Singh, B., Kumar, A. and Sharma, R.K. (2014) Effect of Waste Materials on Strength Characteristics of Local Clay. Int. J. Civil. Eng. Res. 5 (1), 61-68.

Egypt. J. Soil. Sci. 56, No. 4 (2016) 
Tang, C. (2011) Shrinkage and cracking behavior of swelling soil under different temperatures [Internet]. [Cited 3 June 2014] Available from: http://www.paper.edu.cn/en_releasepaper/content/4404675

Tang, C., Shi, B., Liu, C., Zhao, L. and Wang, B. (2008) Influencing factors of geometrical structure of surface shrinkage cracks in clayey soils. Eng. Geol. 101, 204-217.

Tang, C.S., Shi, B.; Liu, C.; Suo, W.B. and Gao, L. (2011) Experimental characterization of shrinkage and desiccation cracking in thin clay layer. Appl. Clay Sci. 52, 69-77.

Tariful, M.I., Sulaiman, W.H.W. and Ahmad, D. (1999) A Modified Technique for Measuring Shrinkage of Clay Soils. Pertanika J. Trap. Agric. Sci. 22 (1), 25-32.

(Received: $23 / 8 / 2015$

accepted: $30 / 12 / 2015)$ 


\title{
تقدير قرة مصاصة قصب السكر علي تقليل شقوق الأراضي الطينية باستخدام تقتية معالجة الصور : تجربة معلية معلية
}

\author{
عبد الحليم عوض عبد الحليم \\ قسم الأر اضي و المياه ـ كلية الزر اعة اليم ـ جامعة طنطا ـ مصر
}

\begin{abstract}
تتحكم الثقوق الناتجة عن جفاف الأر اضي الزر اعية الطينية بدرجة كبيره في معدل

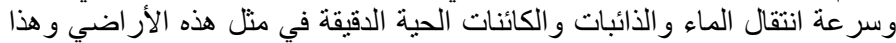
يؤثر معنويا علي نمو و إنتاجية المحاصيل.

تهدف هذه الدراسة للتحقيق في تأثير إضافة مصاصة قصب السكر كأحد

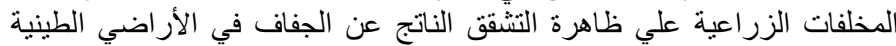

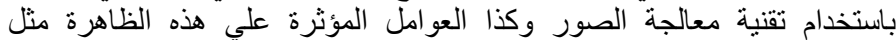

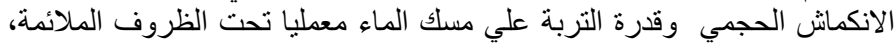

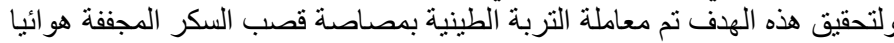

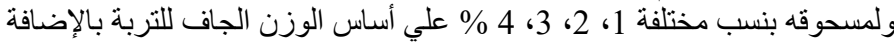

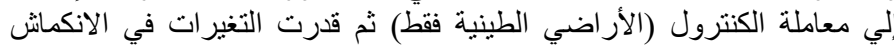

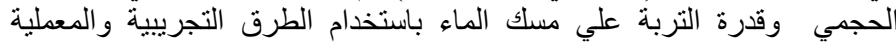
المناسبة وكذا كثافة الثقوق اللسطحية واتساع هذه الثقوق باستخدام تقنية معالجة الصور بيرنامج 1.47 الصنافية $1.4 m a g e J$ ver.

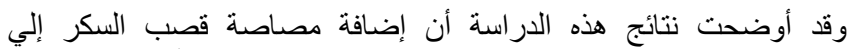

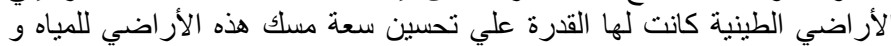

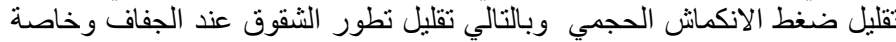
عند خلطهما معا بنسب تتر اوح بين 1 إلي 2\% علي أسلي أساس الوزن الجاف للتربة.

توصي هذه الدراسة بأن إضافة مصاصة قصب الإبـ السكر كأحد المخلفات

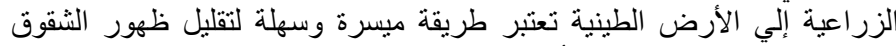

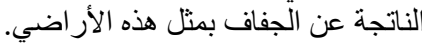

